\title{
冬期建築工事の増工費の算定方式
}

\author{
（第 3 報・算定手法および算定方式の実用性の検証）
}

正会員中村裕史*

第 1 報では増工費の主要因とその冬期工法等の設定に ついて, 第 2 報では主増工費の算定処理方針々算定処理 データの設定についてそれぞれ報告した。ここでは主増 工費の具体的な算定手法と増工費算定のとりまとめ，お よび算定方式の実用性の検証について述べる。

\section{§1. 算定手法}

1.1 冬期工程図の作成基準

この算定方式においては第 2 報\$1.の算定処理方針で 示したよらに, 入力データの多くを工程図から拾い出す ものである。ここでは算定の精度確保のため，この入力 データ拾い出しの基礎となる冬期部分の工程図（冬期工 程図）の作成法に基隻を設ける。

\section{(1) 冬期工程の修正}

冬期間の工程注常温時に比べ種々の原因から工期が長 引くため, 先ず工程を修正する必要がある。ここでは冬 期工程における標準修正日数を 表一1のように設定す る。設定理由は以下に述べるとおりである（a，b，‥ 表中の記号に対灾している)。

\section{表一1 冬期工程における標準修正日数}

\begin{tabular}{|c|c|c|c|}
\hline & 修 & 項 & 正 \\
\hline & $\begin{array}{l}\text { 作業休止日 } \\
\text { 定 期 } \\
\text { 不 定 期 }\end{array}$ & 正月休 工 $_{x}$ & $\begin{array}{l}\text { 常温特と同じ（敏週日曜日） } \\
12 \text { 月 } 29 \text { 日から1月 } 7 \text { 日まくの10日間 }\end{array}$ \\
\hline b & 作業不能日 & b2 屋内工事*2 & 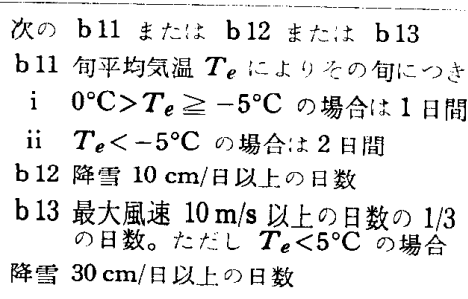 \\
\hline & $\begin{array}{c}\text { 養生日数 } \\
\text { の延長 }\end{array}$ & 躯体工曺 & 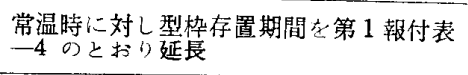 \\
\hline & $\begin{array}{l}\text { 冬期対策 } \\
\text { 専用日 }\end{array}$ & $\left\{\begin{array}{c}\mathrm{d} 1 \text { 着工時除雪 } \\
\text { 専用日 } \\
\mathrm{d} 2 \text { 羙生囲い架 } \\
\text { 設専用日 }\end{array}\right.$ & 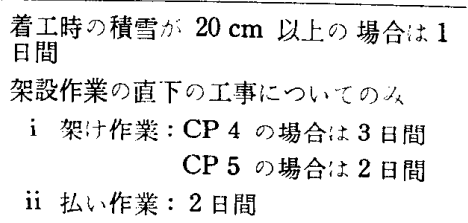 \\
\hline
\end{tabular}

*1 屋外仮設, 土・地業, 鈴骨建方なと作業場が直接外氮にさらされる丁.事

*2*1 以外の屋内（囲い内考主）の工事

*3 团い部位 CP 4, CP 5 の 开

* 北海道立寒地建築研究所

(昭和 50 年 2 月 10 日本稿受理・誩諭期限昭和 51 年 3 月末日) a 正月休みの期間は現状では現場によりまちまちで 場合によっては 1 ケ月上にわたることもある。ここで は冬期工事を積極的に進めることを旨とし，その期閒を 官公庁の御用納めの翌日から七日正月までとした。

b 冬期建筑工事の作業不能日については今のところ 定説はない(13),28) 34)。ここでは次の想定に基づいて作業 不能日を設定した。

b 1 外気に直接さらされる 屋外工事については 次の ように低温, 降雪, 強風を作業不能の原因とした。

b 11 低温については氷点 $\left(0^{\circ} \mathrm{C}\right)$ および無活動耐久限 界点 $\left.\left(-5^{\circ} \mathrm{C}\right)^{9}\right)$ 亿基準を置き，それぞれにおける作業能 率低下率を 10\% および 20\% と想定してこれを作業不 能日に見直した。

b 12 降雪については第 1 報§ 3. の基本適用期間に示 した除雪および間接囲いが必要となる降雪量に基淮を置 き,この場合は頻繁な除雪, 或いは視界不良のため作業 不能になるものとした。

b 13 強風については風力階級 $5(8.0 \sim 10.8 \mathrm{~m} / \mathrm{s})$ 程 度で作業不能になるものと想定し, 気象統計值の整って いる最大風速值 ${ }^{10)}$ に基準を置いた。ただし一日 24 時間 に対寸る作業時間 ( 8 時間) の比率に忘じてその日数を 低減した。また冬期の範囲限定のため気温限界を設け た。

b 2 屋内工事については交通 マヒが生じる, 或いは 全作業者が現場の除雪に動員されると経験的に考えられ る降雪量に基準を置いた。

c 対象としてコンクリート工事と湿式工事が考えら れるが、ここでは JASS 5 に明確な規定のある前者に ついて設定を行なった。

d 工程上, 或いは危険防止上から他の工事を中断し て作業を行なら必要のある冬期対策については, その専 用日を設けるものとした。

d 1 除雪に半日近く以上要すると考えられる 積雪量 に基準を置いた。

$\mathrm{d} 2$ 第 2 報表一2 $(4 ， 5) * \mathrm{a}$ に示寸囲いの標準架設期 間に基づいた。ただし CP 5 はその構造がより簡易であ るため 1 日短縮した。

（2）冬期工程図の作成法

冬期工程図は入力データの拾い出しが容易であること 


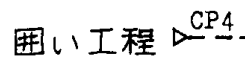

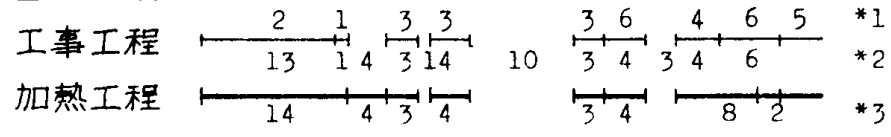

*1 工事種目（記号は表-2（6）I 参照），*2 施工日数，*3 加熱日数

图-1 冬期工程图例

に主眼を固き，概ね次の方法によって作成する（网一1 参照)。

a 表示法はアロ一型ネットワーク・タイムスケール 工程図 ${ }^{35}$ による。

b 表示期間は概ね 10 月〜4 月とする。

c 工程困に示す工事種目，および同一階で複数の工

事種目が 重複する場合の 表示優先順位は次による （趣旨は第 2 報 $2 .(6)$ a に示したょ同じである)。 コンクリート工事>湿式工事>淮湿式工事>型 枠工事 >その他工事>屋外工事（表-1 参照）

d 内外仕上工事の工程は各階ごとに分けて表示 する。

e 養生囲いと養生加熱の工程は第 2 報表一2（4～6） に示すそれぞれの工程計画基淮に従って表示する。

1.2 入力データの拾い出し基蕉

この算定方式において入力データおよびその拾い出し 法の基準は表一2（1）（7）に示すとおりとする。

粹一2 入力データとその拾い出し基集（数值沬（6）AR を除き整数とする。リーダーけい以下は例示闌） (1) 仮設建物暖房

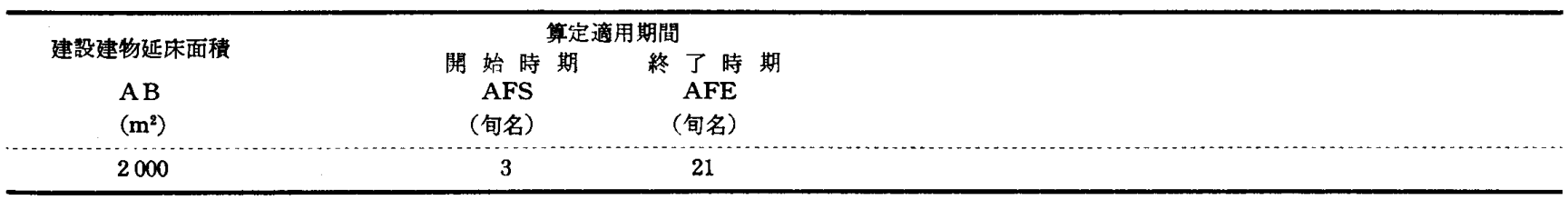

AFS, AFE : 算定適用期間とは算定しょうとする工事の工程期間と基本適用期間との一致する期間 工 事 工程 期 間 基本適用期 間

開始時期

算定適用期間

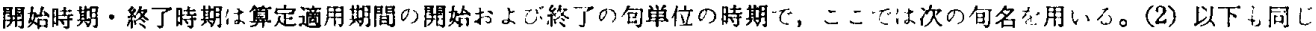

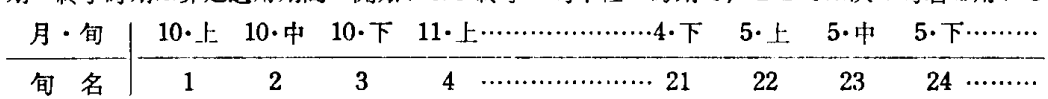

（2）場内外除雪

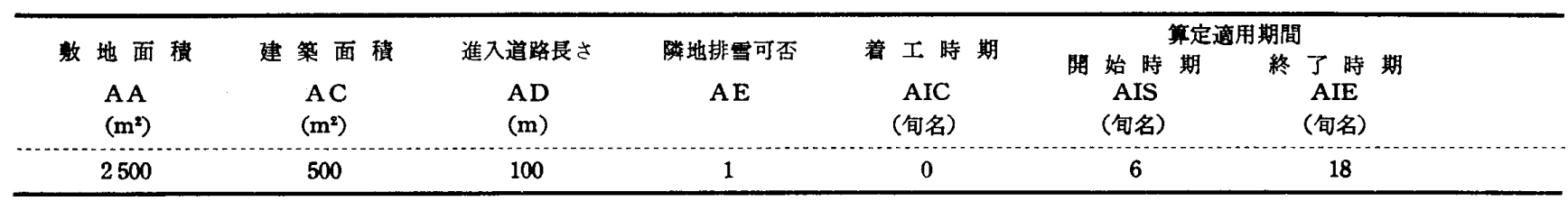

$\mathrm{AD} ：$ 工事現場の主要出入口から主要公道までの距離（第 1 報表一 $-3(2) * 1$ 参照）

$\mathrm{AE}$ ：隣接空地への場内除雪の搬出（排雪）の可否。可 $=1$, 否 $=0$ と与る

AIC : 積筜期間以外の時期の場合は 0 と才る

AIS, AIE : 期間中除雪の算定適用期間の各時期

(3) 材料変更

\begin{tabular}{|c|c|c|c|c|c|c|c|}
\hline $\begin{array}{c}\text { デー夕番号 } \\
\text { (L) }\end{array}$ & $\begin{array}{c}\text { 打 設 時 期 } \\
\text { A J } \\
\text { (旬名) }\end{array}$ & $\begin{array}{c}\text { セメント種類 } \\
\mathrm{AK}\end{array}$ & 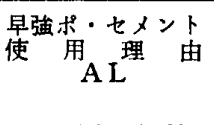 & 打 $\begin{array}{c}\text { 設 } \\
\underset{\left(\mathrm{m}^{8}\right)}{\mathrm{AM}}\end{array}$ & 量 & 備 & 考 \\
\hline (1) & 6 & 1 & 0 & 300 & & $2 F$ & \\
\hline (5) & $\begin{array}{c}\vdots \\
14\end{array}$ & $\vdots$ & $\vdots$ & $\begin{array}{c}\vdots \\
250\end{array}$ & & $6 \vdots$ & \\
\hline
\end{tabular}

$\mathrm{L} ： \mathrm{~L}$ 番目のデータを表わす。本来は各データに添字として $\mathrm{AJ}(\mathrm{L}), \mathrm{AK}(\mathrm{L}), \cdots$ と付くものであるがここでは省略する。(4)以下も同し

$\mathrm{AK} ：$ 普通ポ・セメント $=1$ ，早強ポ・セメント $=2$ とする

$A \mathrm{~L} ：$ 冬期工程の短樎 $=1$, 前記以外 $=0$ とする

茟考：主として施工個所を記入する。(4) 以下を同し

(4) 直接囲い

\begin{tabular}{|c|c|c|c|}
\hline $\begin{array}{c}\text { デー夕番号 } \\
\text { (L) }\end{array}$ & $\begin{array}{c}\text { 困 } \text { 、面 } \\
\text { AO } \\
\left(\mathrm{m}^{2}\right)\end{array}$ & 㑲 & 考 \\
\hline $\begin{array}{c}(1) \\
\vdots \\
\vdots \\
(3)\end{array}$ & $\begin{array}{c}800 \\
\vdots \\
\vdots \\
500\end{array}$ & $\begin{array}{r}4 \mathrm{~F} \\
\vdots \\
6 \\
6 \mathfrak{F}\end{array}$ & \\
\hline
\end{tabular}

$\mathrm{AO}$ : 施工個所ごとの CP 1 CP 3 の团い表面積の総和（第 1 報付困一1 照）

$-2-$ 


\begin{tabular}{|c|c|c|c|c|c|c|c|c|c|c|c|c|}
\hline $\begin{array}{c}\text { デー夕番号 } \\
(\mathrm{J}, \mathrm{K}, \mathrm{L})\end{array}$ & 困 & $\begin{array}{l}\text { 小面 㮐 } \\
\mathrm{AO} \\
\left(\mathrm{m}^{2}\right)\end{array}$ & 国 & 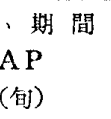 & & 嘴 & 考 & & & & & \\
\hline $\begin{array}{c}(1,5,1) \\
(1,5,2) \\
\vdots \\
(8,8,5)\end{array}$ & & $\begin{array}{c}650 \\
650 \\
\vdots \\
90\end{array}$ & & $\begin{array}{l}5 \\
6 \\
\vdots \\
-\end{array}$ & & $\begin{array}{l}F \sim 3 F \\
4 F \sim 5 F \\
\vdots \\
5 \dot{F}\end{array}$ & & & & & & \\
\hline 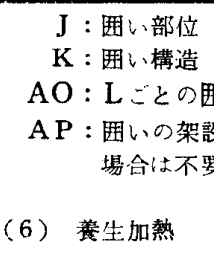 & $\begin{array}{l}\text { 報付图- } \\
\text { 報付表 } \\
\text { 表面積 } \\
\text { 日。 } \mathrm{AP}=\text { f }\end{array}$ & 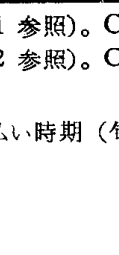 & $\begin{array}{l}\mathrm{P} 4=1, \mathrm{Cl} \\
\mathrm{K} 1=1, \mathrm{C}\end{array}$ & $\begin{array}{l}5=2, \mathrm{Cl} \\
\mathrm{K} 21=2, \\
\text { 時期（旬名 }\end{array}$ & $\begin{array}{l}\begin{array}{l}6=3, \mathrm{CP} \\
\mathrm{K} 22=3, \\
\text { とする。 }\end{array} \\
\end{array}$ & 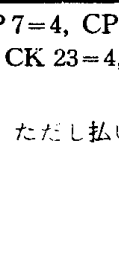 & $\begin{array}{l}8=5, \text { CP } 9= \\
\text { CK } 24=5, \\
6 \text { 時期と架け }\end{array}$ & $\begin{array}{l}=6, \mathrm{CP} 10 \\
\mathrm{CK} 31=6\end{array}$ & $\begin{array}{l}=7, \text { CP } 1 \\
\text { CK } 32= \\
\text { 場合は A }\end{array}$ & $\begin{array}{l}=8 \text { とする } \\
\text { 7, CK } 4=8 \\
=1 \text { となる }\end{array}$ & $\mathrm{K}=1$, & 80 \\
\hline デー夕翻号 & \multirow{2}{*}{$\begin{array}{c}\text { 加熱洔期 } \\
\text { A J } \\
\text { (旬名) }\end{array}$} & \multirow{2}{*}{$\begin{array}{c}\text { 加熱日数 } \\
\text { A R } \\
\text { (日) }\end{array}$} & \multirow{2}{*}{$\begin{array}{c}\text { 加熱温度 } \\
\mathrm{AQ} \\
\left({ }^{\circ} \mathrm{C}\right)\end{array}$} & \multicolumn{2}{|r|}{ 加 熱 } & 空 間 & 各 部 表 & 面 䆅 & & \multirow{2}{*}{$\begin{array}{c}\text { 加熱容積 } \\
\text { AT } \\
\left(\mathrm{m}^{3}\right)\end{array}$} & \multirow{2}{*}{\multicolumn{2}{|c|}{ 備 }} \\
\hline$(\mathrm{I}, \mathrm{J}, \mathrm{K}, \mathrm{L})$ & & & & $\overparen{\mathrm{ASF} 1}$ & $\overline{\mathrm{ASF}} 2$ & ASW 1 & $\frac{\text { 壁 }}{\text { ASW } 2}$ & $\frac{\text { 天 }}{\text { ASC } 1}$ & $\frac{\text { 井 }}{\mathrm{ASC} 2}$ & & & \\
\hline$(1,1,1,1)$ & 6 & 4 & 5 & 0 & 0 & 0 & 0 & 350 & 50 & 950 & B2 & \\
\hline $\begin{array}{c}(1,1,1,2) \\
\vdots \\
(6,2,2,3)\end{array}$ & $\begin{array}{c}8 \\
\vdots \\
18\end{array}$ & $\begin{array}{c}5.5 \\
\vdots \\
16\end{array}$ & $\begin{array}{l}6 \\
\vdots \\
5\end{array}$ & $\begin{array}{c}0 \\
\vdots \\
400\end{array}$ & $\begin{array}{l}0 \\
\vdots \\
0\end{array}$ & $\begin{array}{c}0 \\
\vdots \\
250\end{array}$ & $\begin{array}{c}0 \\
\vdots \\
50\end{array}$ & $\begin{array}{c}350 \\
\vdots \\
400\end{array}$ & $\begin{array}{c}50 \\
\vdots \\
0\end{array}$ & $\begin{array}{c}950 \\
\vdots \\
900\end{array}$ & $\begin{array}{c}\mathrm{B} 1 \\
\vdots \\
3 \mathrm{~F}\end{array}$ & \\
\hline
\end{tabular}

I：工事種目。コンクリート $=1$, 型枠組立 $=2$, 型枠解体 $=3$, 湿式 $=4$ ，染湿式 $=5$ ，その他 $=6$ と与る

$\mathrm{J}:$ 仕上工事の内外別。外仕上 $=1$, 内仕上 $=2$ とする。ただし $\mathrm{I}=1 \sim 3$ の場合法 $\mathrm{J}=1$ とする

$\mathrm{K}:$ 施工階。地下 $=1$, 地上 $=2$, 屋上 $=3$, 基礎 $=4$ とする

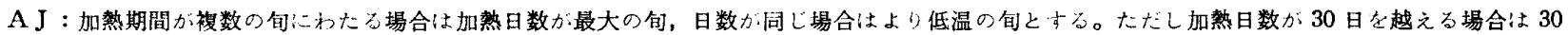
日ごとに区切る

$\mathrm{AR} ： \mathrm{I}=4$ ○)場合は $\mathrm{AR}=5, \quad \mathrm{I}=5$ の場合は $\mathrm{AR}=3$ (アスファルト 3 首防水の場合は $\mathrm{AR}=9$ ）と寸る（まる施工個所に $n$ 日かかる場合， との施工個所 (加熱空間) $n$ 個に仕切り，1日の施工量仕 $1 / n$ の施工個所と想定寸る)

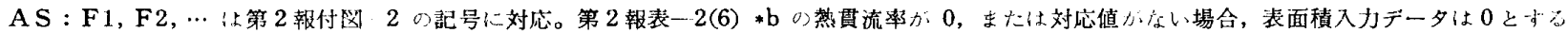

(7) 材料加熱

\begin{tabular}{|c|c|c|c|c|c|c|c|}
\hline $\begin{array}{c}F-\text { 番 品 } \\
(J, L)\end{array}$ & 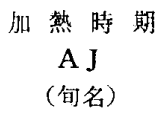 & $\begin{array}{l}\text { 工地 数 } \\
\mathrm{AU} \\
\text { (日) }\end{array}$ & $\begin{array}{c}\text { 工面 皘 } \\
\mathrm{AW} \\
\left(\mathrm{m}^{2}\right)\end{array}$ & $\begin{array}{c}\text { 施 工厚 } \\
\mathrm{AX}\end{array}$ & $\begin{array}{l}\text { 裸 階 数 } \\
\text { A Y } \\
\text { (倩) }\end{array}$ & 備 & 考 \\
\hline$(1,1)$ & 15 & 3 & 120 & 1 & 3 & $1 \mathrm{~F}, 1$ & \\
\hline$(1,2)$ & 17 & $\begin{array}{l}7 \\
\vdots\end{array}$ & $\begin{array}{c}120 \\
\vdots\end{array}$ & $\begin{array}{l}2 \\
\vdots\end{array}$ & 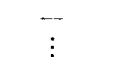 & $\begin{array}{c}1 \mathrm{~F}, 2 \\
\vdots\end{array}$ & \\
\hline$(2,6)$ & 19 & 4 & 540 & 3 & 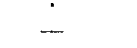 & $4 \mathrm{~F}$ & \\
\hline
\end{tabular}

$\mathrm{J}:$ 仕上工事の内外別。外仕上 $=1$, 内仕上 $=2$ となる

$\mathrm{AU}:$ 図-1*2に相当子る拖工日数

$A W$ : 兒付面耫と寸る

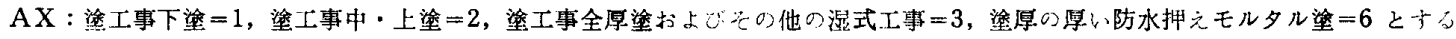

AY：内外別に同時期においに材料加熱が最も多く重複する階数とたる

\section{3 算定処理過程の基淮}

主増工費算定の処理過程は各冬期対策ごと図-2(1)

〜 (7) に示すフローチャートによるものとする。

主増工費のとりまとめは次式による。

$\mathrm{Y} . \mathrm{MA}=\mathrm{Y} \cdot \mathrm{HX}+\mathrm{Y} \cdot \mathrm{SN}+\mathrm{Y} . \mathrm{ZC}+\mathrm{Y} \cdot \mathrm{CD}$

$$
+\mathrm{Y} \cdot \mathrm{CI}+\mathrm{Y} \cdot \mathrm{HY}+\mathrm{Y} \cdot \mathrm{HZ}
$$

ここに

Y.MA：堷工費 (円)

Y.HX, ․: 図-2 に示す各冬期対策の増工費 (円)

\section{§2. 増工費算定のよりま亡め}

2.1 副増工費と全増工費の算定

副増工費と全増工費の算定は主増工費に基ゔき次式に よる。

$$
\begin{aligned}
& \mathrm{Y} . \mathrm{SA}=0.1 \times \mathrm{Y} . \mathrm{MA} \\
& \mathrm{Y} . \mathrm{TA}=\mathrm{Y} . \mathrm{MA}+\mathrm{Y} . \mathrm{SA}=1.1 \times \mathrm{Y} . \mathrm{MA}
\end{aligned}
$$

ここに

Y.SA : 副増工費。すなわち増工費の要因のうちの 主要因以外の要因に要する増工費（円）

Y.TA：全増工費。すなわちこの算定方式において 最終的に求めるべき増工費（円）

副增工費を主増工費の $10 \%$ としたのは，実態調查の 分析結果 ${ }^{6}$ に基づくものである。すなわち全増工費に対 する主増工費の比率は $91.3 \%$ ，主增工費に対する 副増 工費の比率は 9.53\% であるが，標準偏差 (5.2\%) も勘 案して計算上区切りのよい10\%としたものである。

\section{2 算定結果のとりまとめ}

算定した増工費を各種観点から容易に検討できるよ 5 ，算定結果を表一3（1）（4）のようにとりまとめる。

\section{§. 算定方式の実用性の検証}

ここではこれまでに示した増工費の算定方式の現実へ 
付表一1脳-2 フローチャートの一般䛉男説明（Dはデーター一般を表わす）
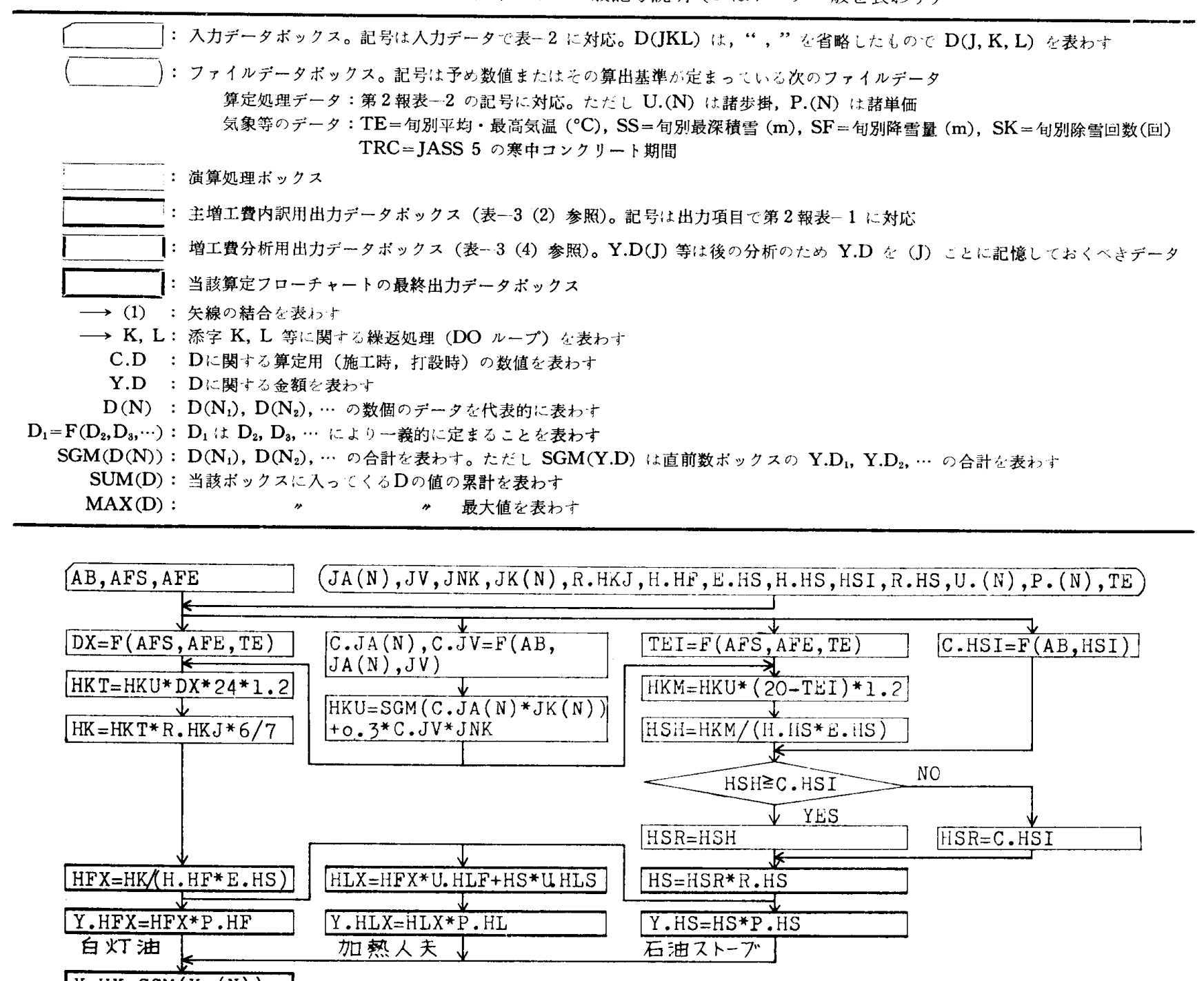

$Y . H X=S G M(Y .(N))$

$\mathrm{DX}$ : 算定期間暖房度日 $\left({ }^{\circ} \mathrm{C}\right.$ 日 $)$

$\mathrm{HK}$ ：供給熱量 (kcal)

HKT : 全" (")

HKM : 最大” ( $\mathrm{kcal} / \mathrm{h})$

$\mathrm{HKU}$ : 単位 " $\left(\mathrm{kcal} /{ }^{\circ} \mathrm{Ch}\right)$

TEI：算定期間旬平均気温の最低値 $\left({ }^{\circ} \mathrm{C}\right)$

HS : 石油ストーフ台数 (台)

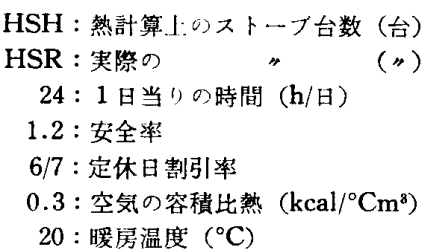

图-2（1）仅設建物暖遊

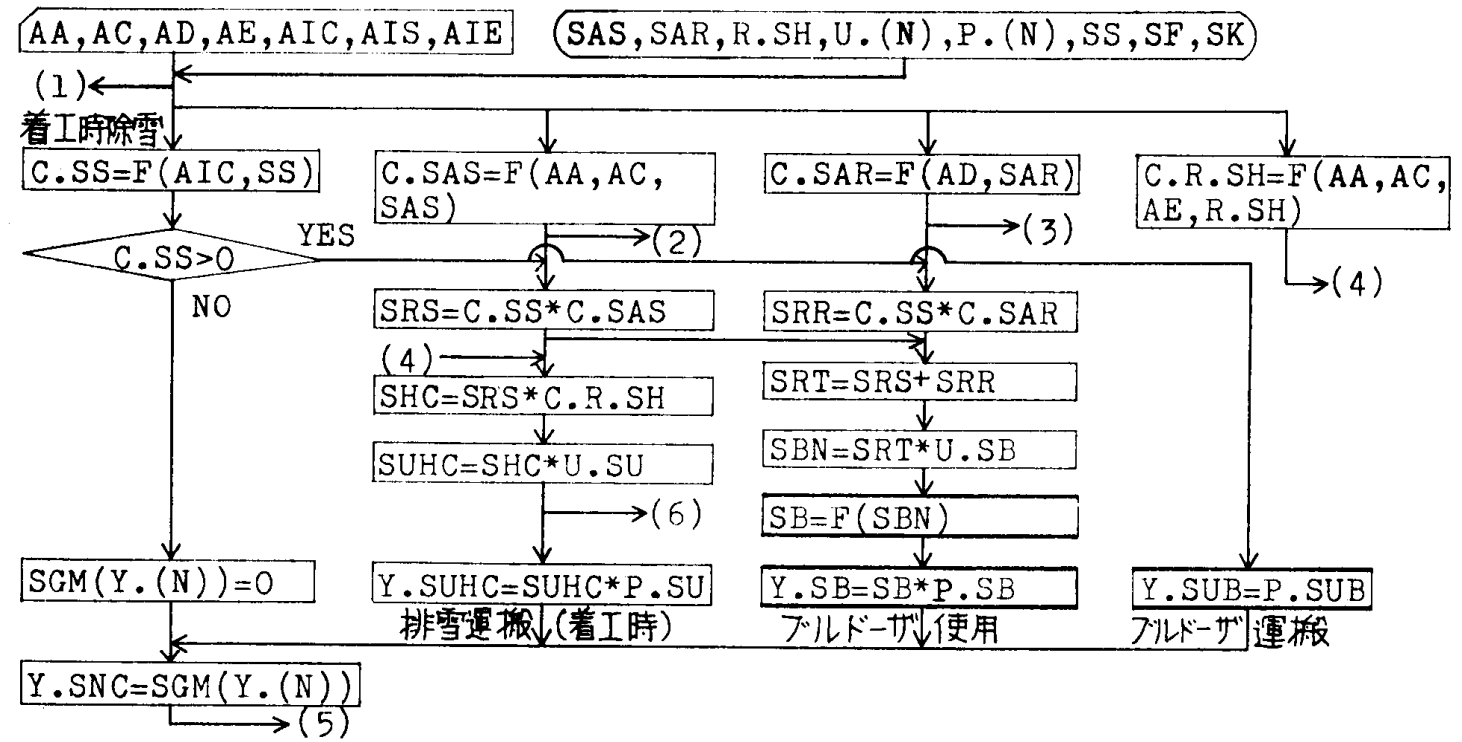




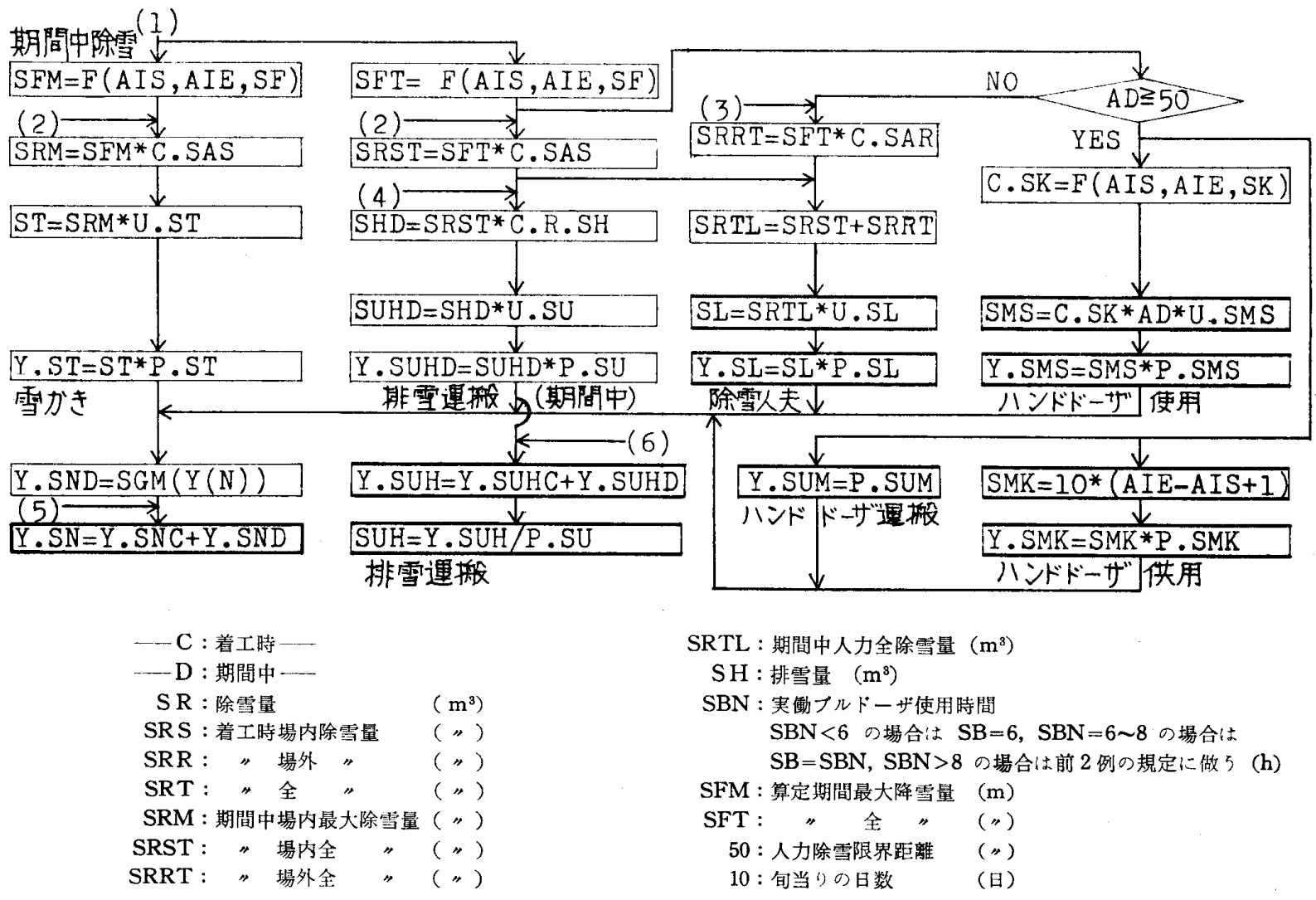

図一2（2）埸内外除露

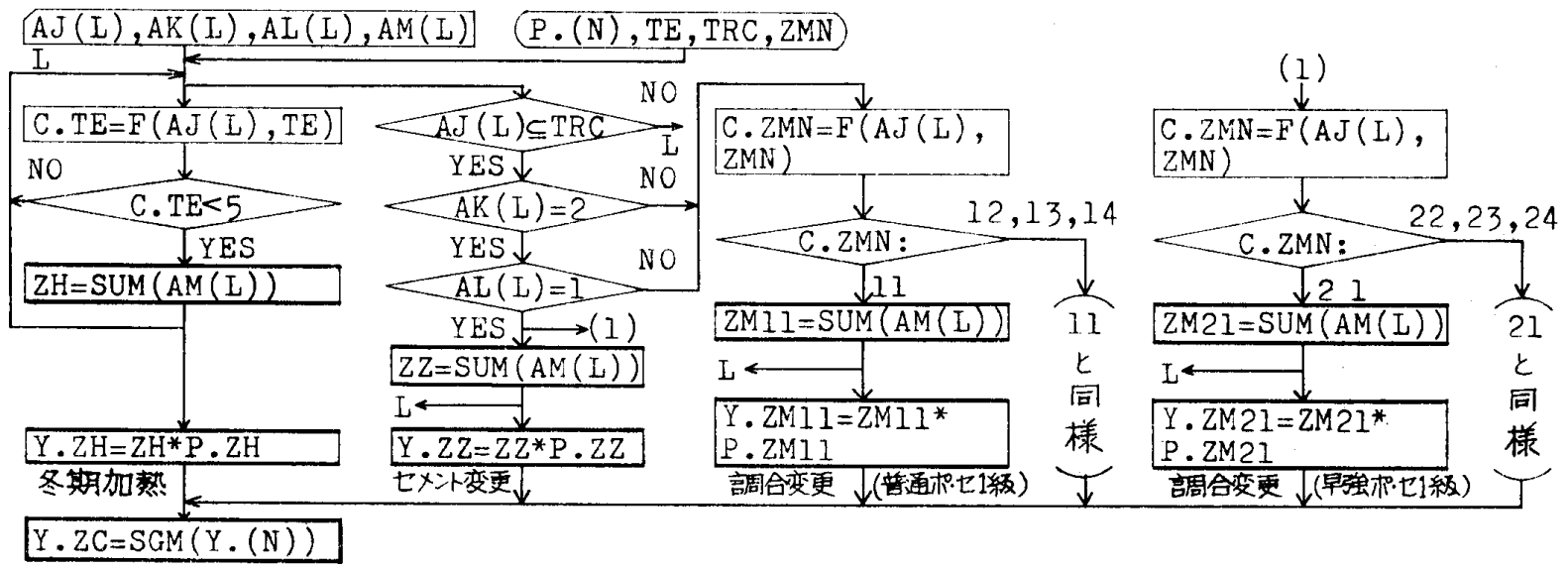

$\subseteq:$ 部分集合記号。すなおわ $\mathrm{AJ}(\mathrm{L})$ は $\mathrm{TRC}$ に含まれら。

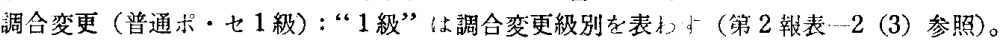

図一2（3）材料变更

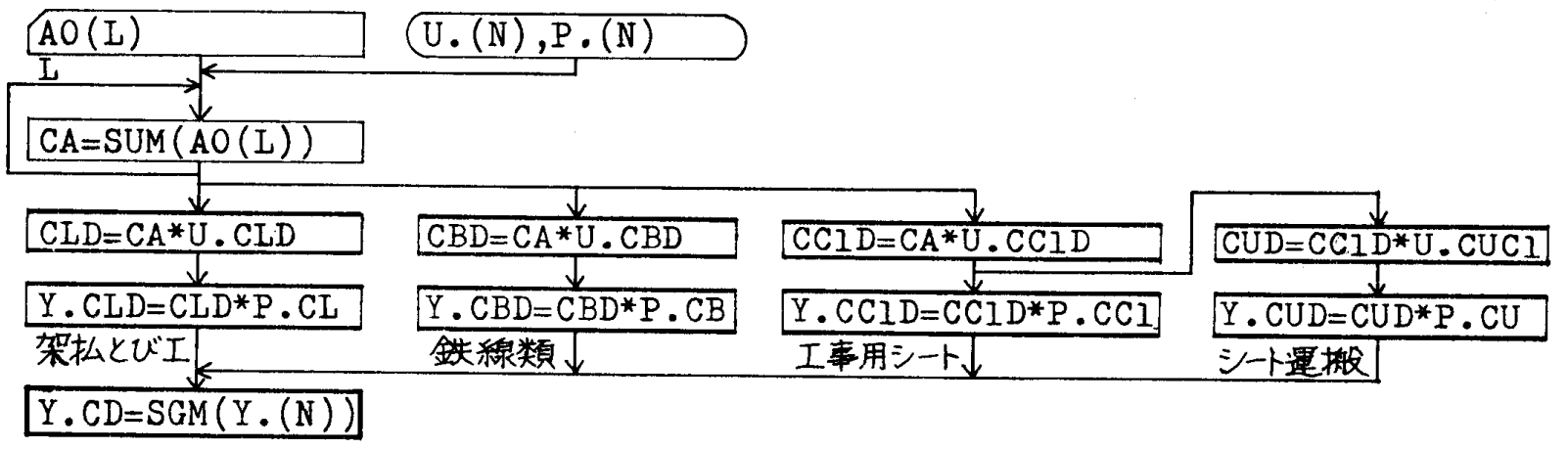

$\mathrm{CA}$ : 累計国い面積 $\left(\mathrm{m}^{2}\right)$

図一2 (4) 直 接囲以 

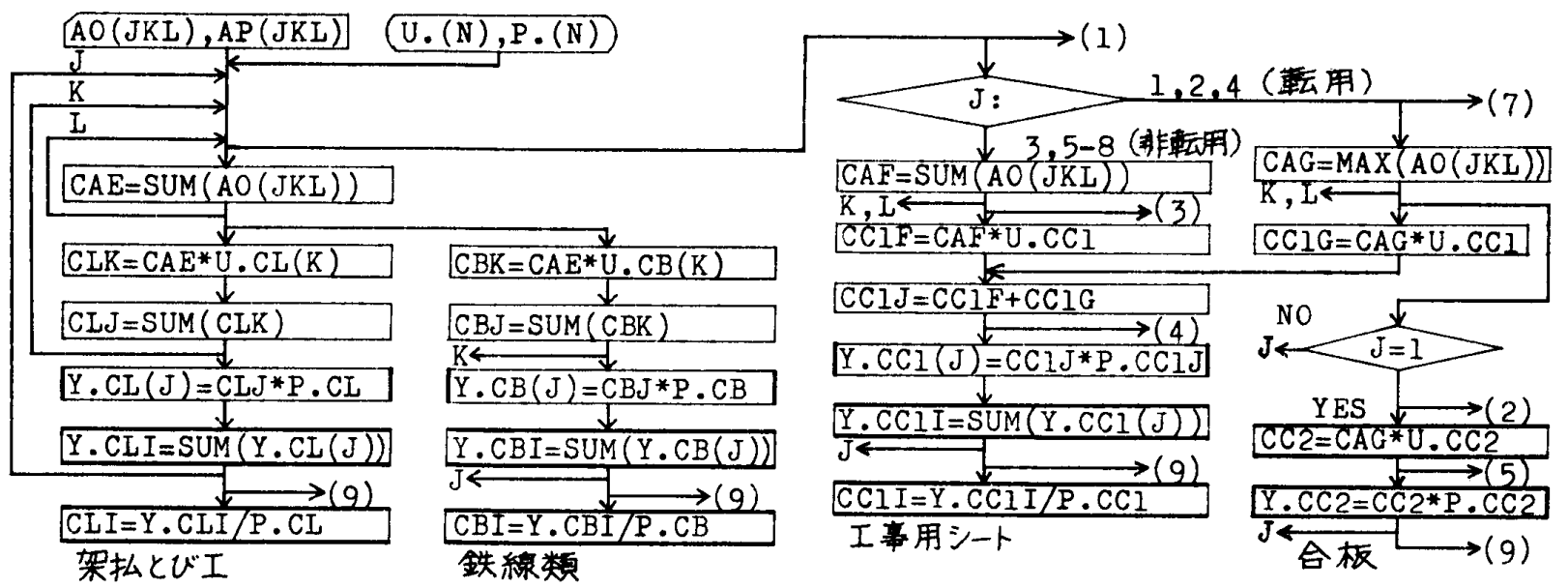

(1)

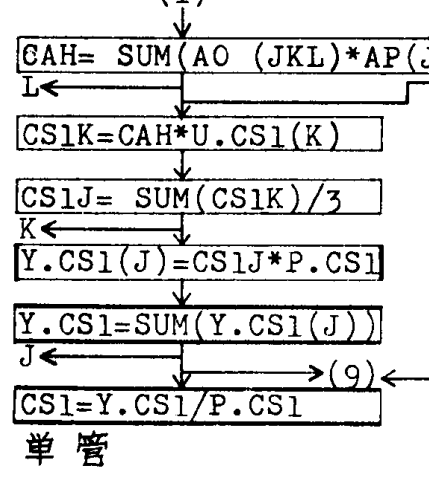

$\overbrace{\operatorname{CS} 1 F=\operatorname{CAP*U} \cdot \operatorname{CS} 1(K)}^{(3)}$

CSIJ $=$ CSIF + CSIM

CUSI $=$ CSI $\frac{\downarrow}{\mathrm{J}^{*} \mathrm{U} . \text { CUSI }}$

$\frac{\downarrow}{\mathrm{W} . \operatorname{CUS1}(\mathrm{J})=\text { CUS1*P.CU }}$

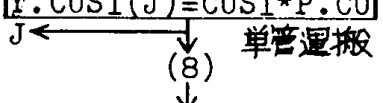

Y.CUI $=$ SGM $(Y . C U(N))$

$\mathrm{CUI}=\mathrm{Y} . \mathrm{CUI} / \mathrm{P} . \mathrm{CU}$

機栈定搬

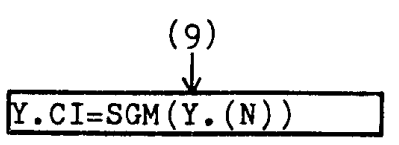

$-\cdots-\mathrm{K}:$ 围い構造別- -

- J : “部位别一

- $\mathrm{M}$ : 最大-一-

$-\mathbf{F}$ : 非枟用-..-

$-G$ : 枟用一

$\mathrm{CA}$ ：围い面皘 $\left(\mathrm{m}^{2}\right)$

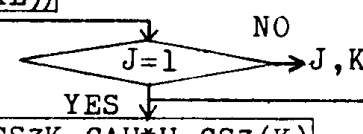

$\frac{\mathrm{YES}}{\mathrm{CS} 3 \mathrm{~K}=\mathrm{CAH}^{*} \mathrm{U} \cdot \operatorname{CS} 3(\mathrm{~K})}$

CS $3=\operatorname{SUM}(\operatorname{CS} 3 K) / 3$

$\frac{\mathrm{K} \leftarrow}{\mathrm{C} \cdot \mathrm{CS} 3=\operatorname{cs}^{*} \mathrm{P} \cdot \mathrm{CS} 3}$

$\mathrm{J} \leftarrow$.

支保梁

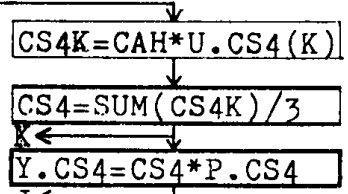

广世

梅組足場

(2)
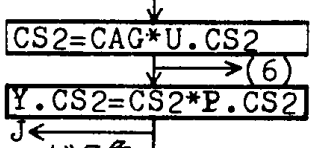

J公角

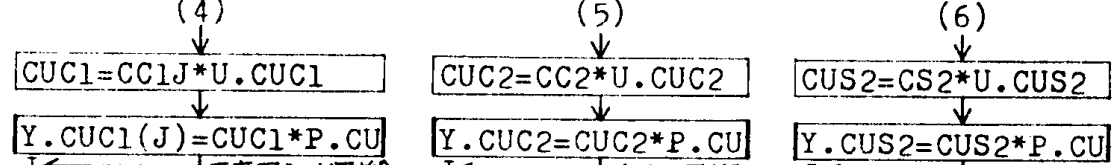

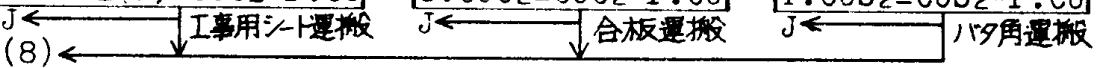

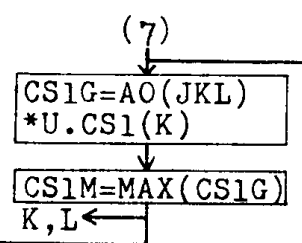

$\frac{\downarrow}{\mathrm{CSIM}=\mathrm{MAX}(\mathrm{CSIG})}$ $\longrightarrow \mathrm{J=I} \longrightarrow \mathrm{J}, \mathrm{K}, \mathrm{L}$ YES

$\mathrm{CS} 3 \mathrm{G}=\mathrm{AO}(\mathrm{JKL}) \quad \mathrm{CS} 4 \mathrm{G}=\mathrm{AO}(\mathrm{JKL})$

*U.CS3 $(\mathrm{K})$

CS3M=MAX (CS3G) CS4M=MAX(CS4G) $K, L \longleftarrow$ CUS $3=$ CS $3 M * U . C U S 3 \quad$ CUS $4=C S 4 M * U$.CUS4 $Y$. CUS $3=$ CUS $3 *$. CU Y.CUS $4=$ CUS $4 * P . C U$ $\mathrm{J} \longleftarrow$ (

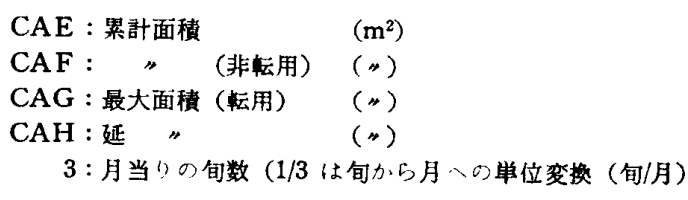

图-2（5）間接囲い 


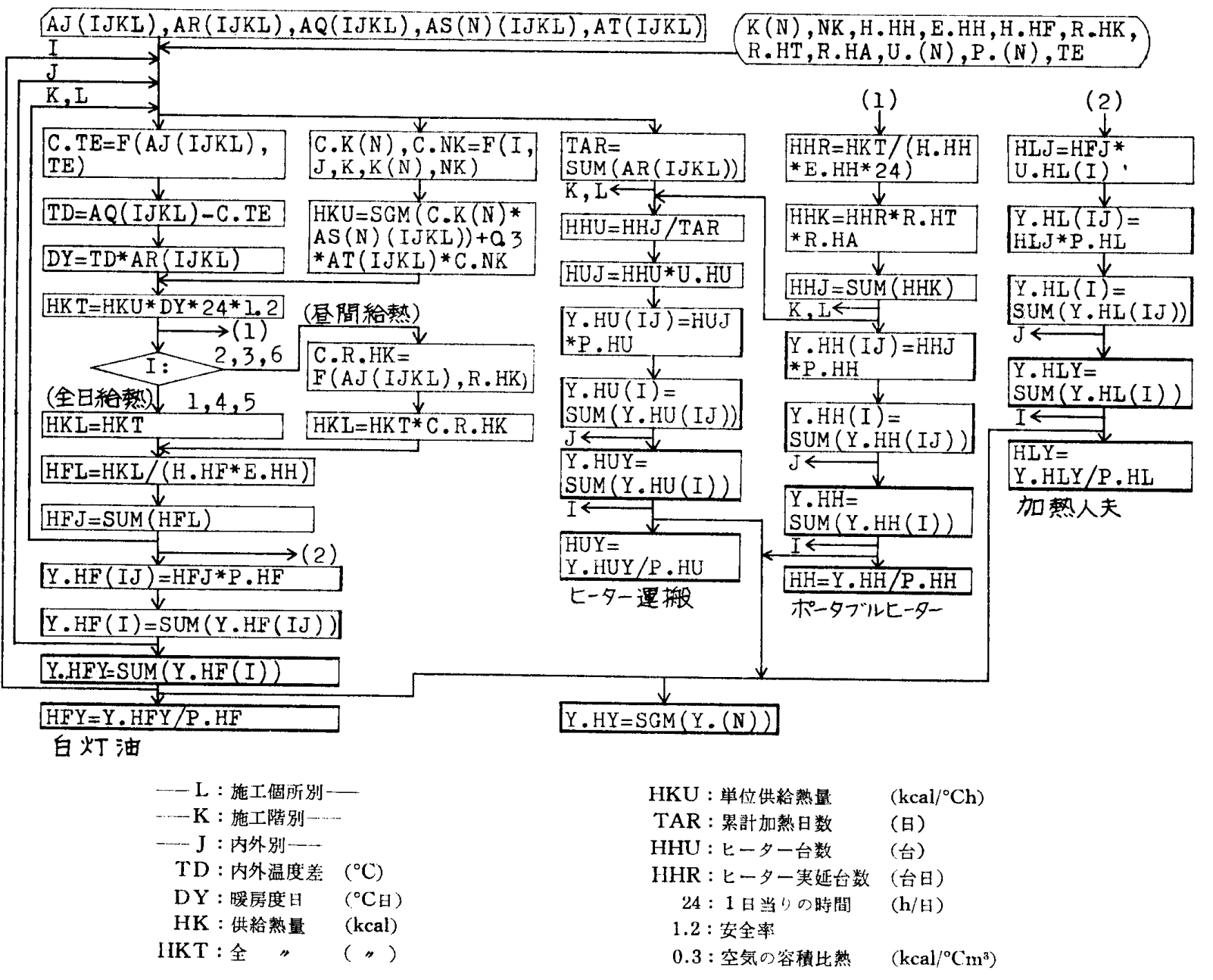

図一（6）養生 加熱

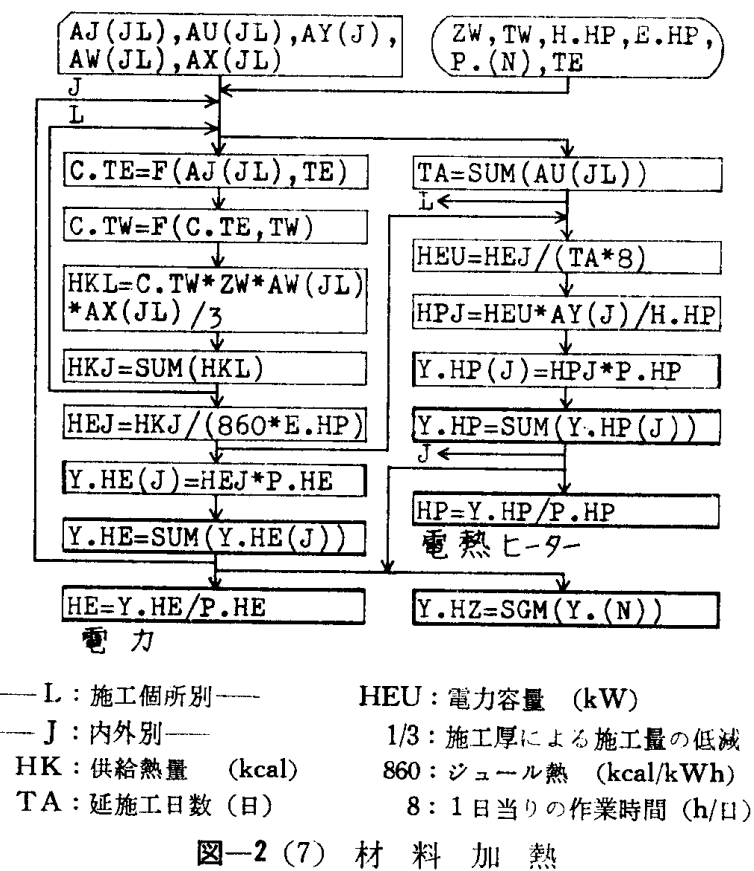

図一2 主増工費算定のフローチャート（一般記号の説明は付表一1） 


\begin{tabular}{cccc|c} 
全 & 增 & 工. & 費 & Y.TA \\
正 & 增 & 工. & 費 & Y.MA \\
副 & 增 & 工. & 費 & Y.SA \\
\hline
\end{tabular}

（2）主增工費の内訳

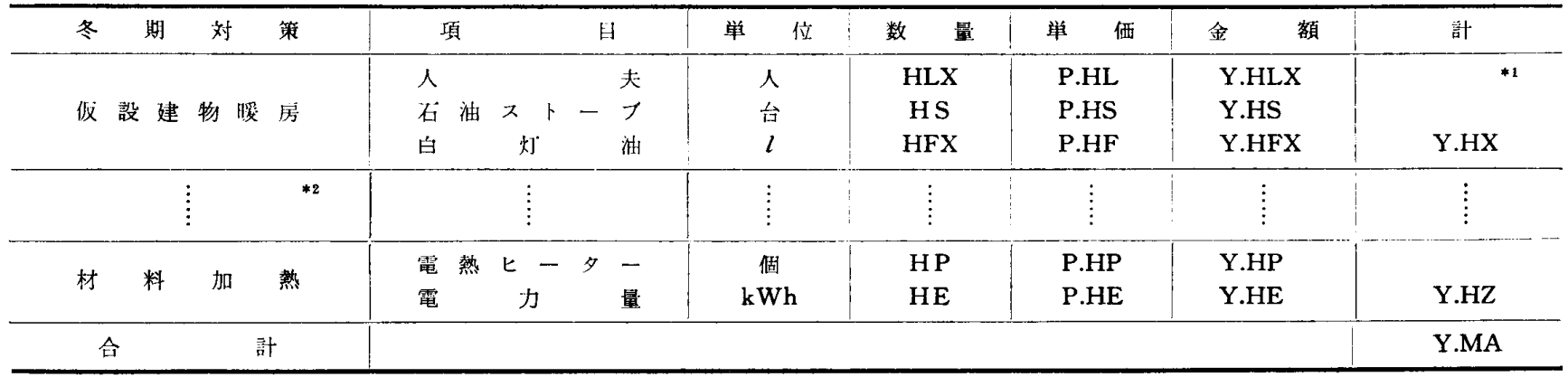

*1 記号は四一 2 k対応

*2省略部分も同様の手法江上る（第 2 報表- 1 参照）

（3）增工費の費目構成

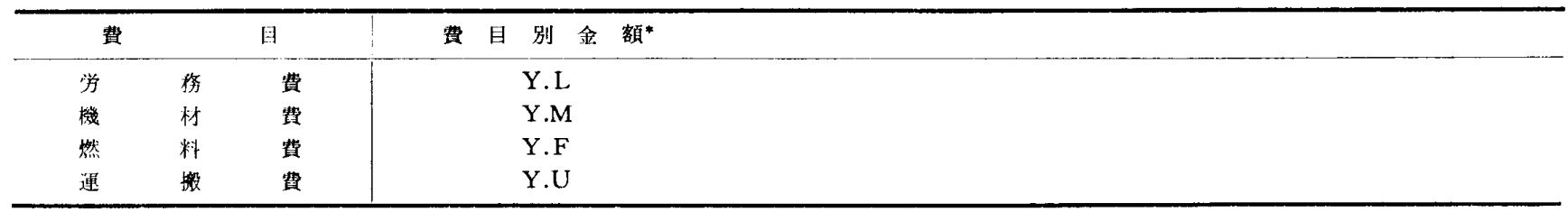

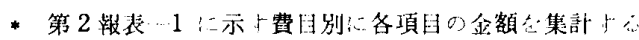

（4）增工費り工事種日，冬期対策構成

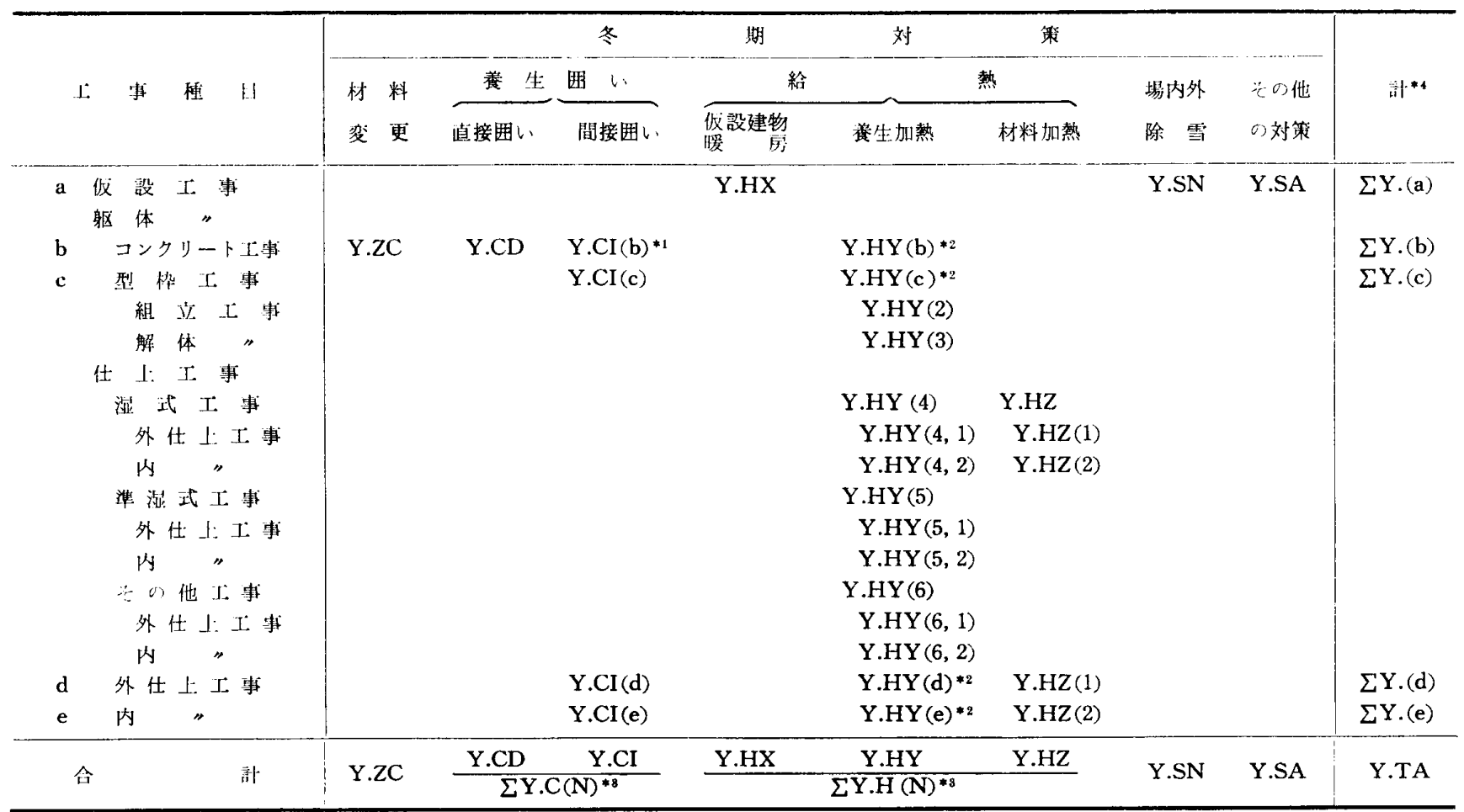

*1 コンクリートエ事 (b) の間接囲い費。Y.CI(b) は次により求ぬる（Y.CI(c)，‥司じ）

1) コンクリート土事に関係与る囲い部位 $(\mathrm{J})$ ごとの間接囲い費 $\mathrm{Y} . \mathrm{CI}(\mathrm{J})$ 算出する

$\mathrm{Y} . \mathrm{CI}(\mathrm{J})=\mathrm{Y} \cdot \mathrm{CL}(\mathrm{J})+\mathrm{Y} . \mathrm{CB}(\mathrm{J})+\mathrm{Y} . \mathrm{CC} 1(\mathrm{~J})+\cdots$

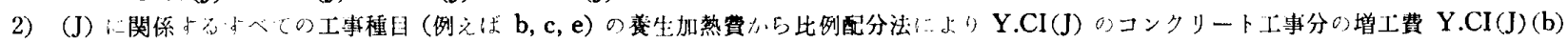
算出打

$\mathrm{Y} . \mathrm{CI}(\mathrm{J})(\mathrm{b})=\mathrm{Y} . \mathrm{CI}(\mathrm{J}) \times \mathrm{Y} . \mathrm{HY}(\mathrm{b}) /(\mathrm{Y} . \mathrm{HY}(\mathrm{b})+\mathrm{Y} . \mathrm{HY}(\mathrm{c})+\mathrm{Y} . \mathrm{HY}(\mathrm{e}))$

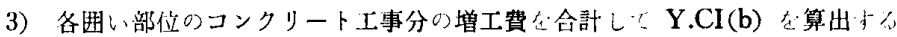

$\mathrm{Y} . \mathrm{CI}(\mathrm{b})=\sum \mathrm{Y} \cdot \mathrm{CI}(\mathrm{J})(\mathrm{b})=\mathrm{Y} . \mathrm{CI}(1)(\mathrm{b})+\mathrm{Y} . \mathrm{CI}(2)(\mathrm{b})+\cdots$

*2 Y.HY(b) =Y.HY(1), Y.HY(c) =Y.HY(2) +Y.HY(3), Y.HY(d) $=$ Y.HY $(4,1)+Y . H Y(5,1)+Y . H Y(6,1), Y . H Y(e)=Y . H Y(4,2)$ $+\mathrm{Y} . \mathrm{HY}(5,2)+\mathrm{Y} . \mathrm{HY}(6,2)$

*3 $\quad \Sigma \mathrm{Y} . \mathrm{C}(\mathrm{N})=\mathrm{Y} . \mathrm{CD}+\mathrm{Y} . \mathrm{CI}, \quad \Sigma \mathrm{Y} . \mathrm{H}(\mathrm{N})=\mathrm{Y} . \mathrm{HX}+\mathrm{Y} . \mathrm{HY}+\mathrm{Y} . \mathrm{HZ}$

*4 各行の合計。 $\Sigma Y .(a)=Y . H X+Y . S N+Y . S A ， \Sigma Y$.(b) 以下屯同し

$-8-$ 
表-4 モデル建物と工事条件の概婪（建設地は札槕）

\begin{tabular}{|c|c|c|c|c|c|c|}
\hline 乱号 & 建物種別 & 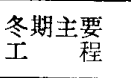 & 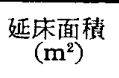 & 地竹，数上: & 構造 & $\begin{array}{l}\text { 実謿日数 } \\
\text { (日) }\end{array}$ \\
\hline $\begin{array}{l}1 \mathrm{Sb} \\
2 \mathrm{Sa}\end{array}$ & アパート & $\begin{array}{l}\text { 地上躯体 } \\
\text { 地下 } " \text { ) }\end{array}$ & 1920 & $0+5$ & $\mathrm{RC}$ & 199 \\
\hline $\left.\begin{array}{l}2 \mathrm{Sb} \\
2 \mathrm{Sc}\end{array}\right\}$ & 事挍所 & $\left.\begin{array}{ll}\text { 地上 } & \\
\text { 仕 } & \text { 上. }\end{array}\right\}$ & 9064 & $2+8$ & SRC & 442 \\
\hline $3 \mathrm{Sb}$ & 学 校 & 地上躯体 & 5448 & $0+4$ & RC & 289 \\
\hline
\end{tabular}

表一5 モデル建物の建築工事賴, 全增工蛽, 增工費率

\begin{tabular}{|c|c|c|c|c|c|}
\hline 苚㕺 & 建物種別 & $\begin{array}{l}\text { 工事単価 } \\
\left(\text { 田 } / \mathrm{m}^{2}\right)\end{array}$ & $\begin{array}{l}\text { 建築工事費 } \\
\text { Y.B(千开円) }\end{array}$ & $\begin{array}{c}\text { 全增工費 } \\
\text { Y.TA(円) }\end{array}$ & $\begin{array}{c}\text { 增工費率 } \\
\mathrm{Y} . \mathrm{TA} / \mathrm{Y} . \mathrm{B} \\
(\%)\end{array}$ \\
\hline $1 \mathrm{Sb}$ & アパート & 32000 & 61440 & 6863447 & 11.2 \\
\hline $2 \mathrm{Sa}$ & & & & 7624531 & 1.4 \\
\hline $\begin{array}{l}2 \mathrm{Sb} \\
2 \mathrm{Sc}\end{array}$ & 事 務 所 & 60000 & 543840 & $\begin{array}{r}14364259 \\
8563597\end{array}$ & $\begin{array}{l}2.6 \\
1.6\end{array}$ \\
\hline $3 \mathrm{Sb}$ & 学 & 45000 & 245160 & 18086274 & 7.4 \\
\hline
\end{tabular}

の適用性について検証する。検証の手法は, 想定したモ デル建物の増工費をここに示した算定方式によって算定 し，これと実態調査の結果 ${ }^{32 \text {-6) }}$ 上対比させる方法によ る。

3.1 モデル建物とその增工費算定

モデル建物とその工事条件の概要を表一4に示す。モ デル建物には規模, 構造等の異なる典型例 3 種を選び, 冬期主要工程は增工費が最大になると考えられる地上躯 体を，更に規模最大のモデル建物（事務所）については これと異なる 2 種の工程を想定した。

増工費の算定は 1. 算定手法に従って冬期工程図と 人カデータ表を作成し，これに基づき演算を電子式卓上 計算機により行なった。モデル建物の建築工事単価と増 工費算定用単価 (P. (N)) は, 実態調查事例との比較を 容易にするため昭和 47 年度調査 ${ }^{\text {( }}$ のもを用いた。算 定の最終結果は表一 5 に示すとおりである。

3.2 モデル建物と実態調查事例の増工費比較

（1）増工費率の比較

モデル建物と調查事例の増工費率の比較を図一 3 に示 す。これによればモデル建物の増工費は調查事例のそれ より全般的に高めとなっているが，これは主として次の 理由によるものと考えられる。

a 冬期間の工事進渉状況がモデル建物では常温時と 変らないのに対し，調查事例では一般に控え目である。

b モデル建物に比べて, 調查事例に扔いては冬期詨 策, 特に養生加熱の程度が低い。

以上の観点から調查事例の工事進渉状況々冬期対策程 度がモデル建物のそれと同様であれば, 両者の増工費率 の相違は極めて小さくなるものと考えられる。

（2）増工費構成の比較

モデル建物と調查事例の増工費の各種構成の比較を表 -6に示す。ここでは各種単価が同じである昭和 47 年 度冬期の調査事例との比較を行なっている。

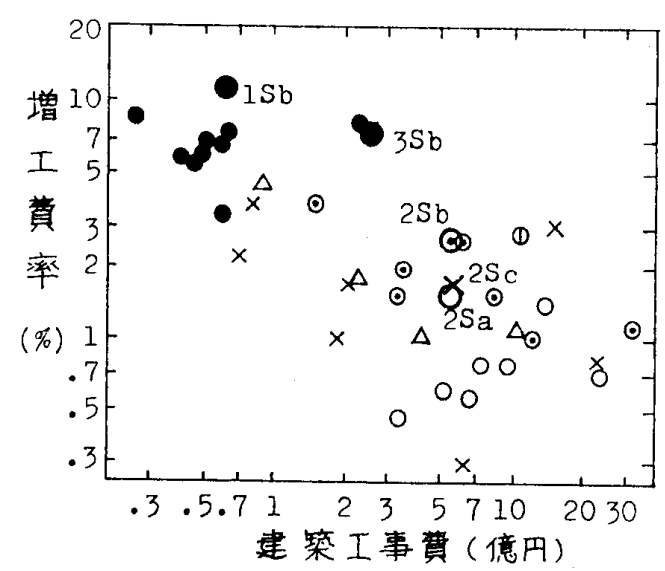

$\begin{array}{ll}\text { (1): 地下躯体, 無 (支保用補助材) } & \text { : 地上躯体, 然 } \\ O: \text {, 有 } & \bigcirc: " \text {, 有 } \\ \triangle: \text { 躯体 }+ \text { 仕上 } & \times: \text { 上, }\end{array}$

図ー3モデル建物と洞查事例の増工費率の比較

a 主要因構成の比較 : 地下躯体工程（2 Sa）を除き モデル建物々調查事例の主要因構成は，ほぼ一致してい る。2 Sa の材料変更費が第 1 位となっているのは，コン クリートの調合変更級別が実態調查では $280^{\circ} \mathrm{D} \cdot \mathrm{D}$ まで であったのをこの算定方式においては $210^{\circ} \mathrm{D} \cdot \mathrm{D}$ まで 延長して細分したことにより単価がより高くなったた めである。地下躯体工程は他の工程に比べて材料変更費 の比重が大きいためこの影響が特に目立っで表われたも のである。

b 工事種目構成の比較：モデル建物の仮設工事費の 比率が調查事例のそれを大きく上回っている。これは “その他の対策費” がモデル建物では一括して仮設工事 費に算入されているのに対し, 調查事例ではこれが各工 事に配分されているためである。地下および地上の躯体 工程において調查事例の内外仕上工事費が零となってい るのは, 工事量が僅少なためその増工費が躯体工事費に まとめて算入されたことによる。調查事例の躯体工事費 の比率がモデル建物のそれを上回っているのは前述の 2 つの理由に基づくものである。

c 冬期対策構成の比較: モデル建物之調查事例の比 率構成に 2, 3 の相違がみられるのはそれぞれ次の理由 によるものである。地下躯体工程の材料変更費の違いに ついては a で述べたと同じ理由による。調查事例と比 ベ，モデル建物において全般に養生囲い費と対比した給 熱費の優越性が認められるのは，モデル建物における養 生加熱の程度がより高いことによるものである。モデル 建物の “その他の対策費” の比率がより高いのはbの冒 頭で述べたと同趣旨の理由による。

$\mathrm{d}$ 費目構成の比較 : モデル建物と調查事例の比摔構 成はよく一致している。

3.3 結 論

モデル建物と実態調查事例との増工費率および増工費 構成の比較に扔いて若干の相異は認められるが, これは 
表一6 モデル建物と調査事(例の增工費檴成の比較

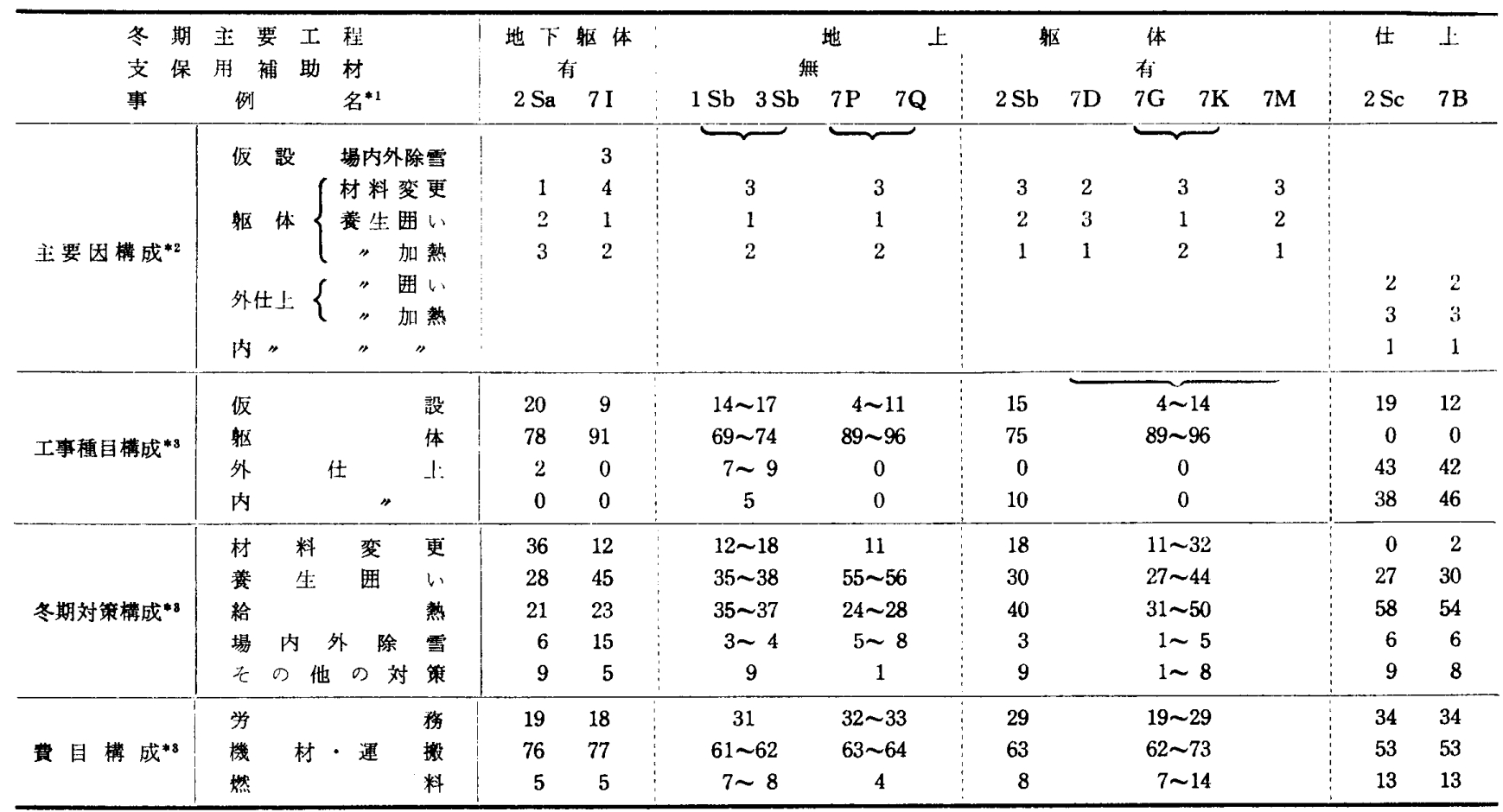

*1 モデル建物 $=2 \mathrm{Sa}, 1 \mathrm{Sb}, \cdots$, 調査事例 $=7 \mathrm{I}, 7 \mathrm{P}, \cdots$ (昭和 47 年度調査 ${ }^{5}$ )

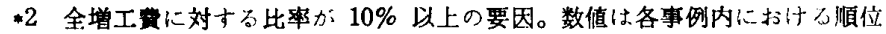

*3 全增工貫に対な万各項目の比率 (\%)

上述のように主として両者の工事状況，或いは增工費の 集計法の違いに基づく表面的なものである。従って大局 的にみるならばここに示した增工費の算定方式は現実 への適用性があるものと考える。

\section{§4. まと め}

本報では次のように主増工費算定の具体的手法扝よび 全増工費の算定法を提示し，また本算定方式の実用性を 検証して，増工費算定方式提案のまとめとした。

（1） 主増工費算定の具体的手法として冬期工程図の 作成法, 入力データの拾い出し法, および算定処理法に ついて基準を示した。算定処理法は冬期対策別に入力・ 算定処理データから出カデータ（増工費）までの演算過 程を理論的に順を追った詳細なフローチャートで示し た。

（2）実態調查の分析結果から全增工費は主増工費全 体の約 $10 \%$ 増であることを確認し，本算定方式におい て最終出力項目である全増工費には主増工費全体の 1.1 倍を当てることを提示した。また算定結果の諸検討を容 易ならしめるため増工費の費目別, 工事種目別，および 冬期対策別のとりまとめ法を示した。

（3）本算定方式の実用性を検証し，これを確認しえ た。すなわち本算定方式により算定した 5 種のモデル建 物の增工費と実態調查事例にそれを比較した結果, 両者 の相違は僅少であった。

\section{§5. 結語}

以上， 3 報にわたり冬期建築工事の増工費の算定方式 を提案した。
この算定方式の確立によって，冬期建築工事の増工：費 はかなりの精度をもって算定することができ，また冬期 建築工事の経済性に関する次の上らな検郡が可能とな る。

（1）冬期建築工事の社会的な経済性の検討。

（2）建物の規模，工程等の条件の違いによる冬期工 事の経済性の検討。

（3）各種施工技術の冬期工事の適用に対寸る経済性 の検討, すなわち断熱型枠, 電熱養生, 作業場輻射熱暖 房, 早強系七メントの多用, 壁断熱材の外側打込み工. 法，プレファブ工法，吊足場工法などである。

これらは冬期建筑工事の経済性評価を伴った推進と発 展のために，今後の重要な研究課題と考えられる。なお この算定方式を用いた諸工事条件の違いによる増工費の 変動，およびこの算定方式の簡略法については概に検討 済みであるので別の機会に報告したい。

謝辞 この論文のとりまとめに当り終始ご指導を賜わ った北海道大学洪悦郎教授に梁謝の意を表します。また 実態調查のデータ収集にご協力いただいた中尾隆平，鬼 頭弘一の両氏に感謝いたします。

\section{菘 考 文献}

1） 18）壮第 1 報に，19＜wide> 27）沬第 2 報に示す

28）及川 周：“雪中作業と疲学度”, 日本積雪連合, 1951.7

29）山田三三男，松田良昌：“寒冷と疲労について”，日本積 雪連合, 1952.10

30）中島 亨: “建築歴 その 1 降水量と作業不能日”, 北海 道大学建築工学科卆業論文, 1966.3

31）洪 悦郎 (編)：“「北海道における冬季建設工事実施上の 諸問題」について”, 1967.3 (p. 42〜54 参照) 
32）同上：“「同上」の参考資料（4）冬季建設 西ドイツ連邦 職業紹介，失業保険事務所 経過報告書”’, 1968.2 (p. 28 に作業不能日の定義があるが，その気象限界の設定条件 が複雑で，またわが国の気象統計整備されていないデ ータが必要なため探用できない）
33）同上:“同上」について”, 1968.8 (p. 49〜87 参照)

34）同上：“同上」について”, 1969.3 (p. 7〜25 参照)

35）日本建築学会：“「ネットワークによる工程の計画と管 理」の指針・同解説”, 1968.9

\section{S Y N OPS IS}

U.D.C. $69.003 .1: 693 / 694$

\section{ESTIMATION SYSTEM OF THE ADDITIONAL COSTS OF WINTER BUILDING}

(Part 3 Techniques of Calculation and Inspection of Practicability of the System)

by HIROSHI NAKAMURA, Research engineer of Hokkaido Building Research Institute, Member of A.I.J.

The present part is the last one of the paper, and the following sections are dealt with :

In the section 1, the concrete techniques of calculating the main additional costs are described. In the first place, the methods of making the construction schedule during the winter and of picking up the input data are prescribed. Then the concrete processes of calculating the main additional costs of each winter measure are shown in the form of a flow chart.

In the section 2, the methods of calculating the total additional costs and of assembling the estimated results are described. The total additional costs are to be drawn from the main additional costs multiplied by 1.1 , a figure based on analyses of investigations of the actual winter buildings. The methods of assembling the estimated results are presented in the form in which a variety of analyses of the additional costs can be easily made.

In the section 3, the applicability of the estimation system to the actual is inspected. The additional costs of the model buildings are estimated using the system, and are compared with the data obtained from investigations of the actual winter buildings. The results of the comparison prove the practicability of the system.

In the section 4 , the summary of this part is stated.

In the section 5 , some economic problems of winter building to be studied in the future are proposed. 